\title{
Formulasi Sediaan Salep Dari Ekstrak Daun Katuk (Sauropus androgynus (L.) Merr.)
}

\author{
Lidyawati", Nurul Hidayati, Ria Ceriana \\ Akademi Farmasi YPPM Mandiri, Banda Aceh, Indonesia \\ Email: Lidyawati.mpipa@gmail.com
}

\begin{abstract}
Abstrak-Tanaman katuk (Sauropus androgynus (L.) Merr.) adalah salah satu tanaman yang memiliki senyawa metabolisme sekunder dengan berbagai potensi dan mengandung beberapa senyawa kimia, antara lain alkaloid papaverin, protein, lemak, vitamin, mineral, saponin, flavonoid dan tanin. Daun katuk dapat bekerja sebagai antioksidan karena mengandung senyawa golongan fenol yaitu flavonoid. Potensi daun katuk tersebut juga didukung oleh penelitian tentang aktivitas farmakologi sebagai antibakteri, antihipertensi, antihiperlipidemia, antiinfeksi, antiinflamasi, antianemia dan meningkatkan produksi ASI. Tujuan dari penelitian ini adalah untuk mengetahui apakah daun katuk dapat diformulasikan dalam bentuk sediaan salep. Salep didefinisikan sebagai sediaan setengah padat yang mudah dioleskan dan digunakan sebagai obat luar. Salep juga merupakan salah satu bentuk sediaan dengan konsistensi semisolid yang berminyak dan pada umumnya tidak mengandung air dan mengandung bahan aktif yang dilarutkan atau didispersikan dalam suatu pembawa. Penelitian ini menggunakan 4 perlakuan dengan berbagai konsentrasi yaitu FO: formulasi kontrol basis salep, FI: formulasi sediaan salep ekstrak daun katuk dengan konsentrasi 10\%, FII: formulasi sediaan salep ekstrak daun katuk dengan konsentrasi 15\%, FIII: formulasi sediaan salep ekstrak daun katuk dengan konsentrasi 20\%. Evaluasi terhadap salep menggunakan uji organoleptik, homogenitas, $\mathrm{pH}$, daya sebar, kestabilitas dan iritasi. Hasil dari evaluasi yang dilakukan pada sediaan salep yaitu stabil dan tidak terjadi iritasi pada kulit.
\end{abstract}

Kata Kunci: Formulasi; Ekstrak; Daun Katuk; Salep

Abstract-Katuk (Sauropus androgynus (L.) Merr.) is a plant that has secondary metabolic compounds with various potentials and contains several chemical compounds, including papaverine alkaloids, proteins, fats, vitamins, minerals, saponins, flavonoids and tannins. Katuk leaves can work as antioxidants because they contain phenolic compounds, namely flavonoids. The potential of katuk leaves is also supported by research on pharmacological activities as antibacterial, antihypertensive, antihyperlipidemic, anti-infective, antiinflammatory, antianemic and increasing milk production. The purpose of this study was to determine whether katuk leaves can be formulated in the form of an ointment. Ointment is defined as a semi-solid preparation that is easily applied and used as an external drug. Ointment is also one of the dosage forms with a semisolid consistency that is oily and generally does not contain water and contains the active ingredient dissolved or dispersed in a vehicle. This study used 4 treatments with various concentrations, namely FO: control formulation of ointment base, FI: formulation of katuk leaf extract ointment preparation with $10 \%$ concentration, FII: formulation of katuk leaf extract ointment preparation with $15 \%$ concentration, FIII: formulation of katuk leaf extract ointment preparation with a concentration of $20 \%$. Evaluation of the ointment using organoleptic tests, homogeneity, $\mathrm{pH}$, spreadability, stability and irritation. The results of the evaluation carried out on the ointment preparation were stable and did not irritate the skin.

Keywords: Formulation; Extract; Katuk Leaf; Ointment

\section{PENDAHULUAN}

Indonesia merupakan salah satu negara yang banyak menghasilkan obat - obatan tradisional, salah satunya adalah tanaman katuk. Tanaman katuk ini sering digunakan sebagai obat tradisinoal, yaitu obat untuk memperlancarkan ASI, mengatasi sembelit, menurunkan berat badan, menurukan demam dan diabetes. Potensi daun katuk tersebut juga didukung oleh penelitian tentang aktivitas farmakologi sebagai antibakteri, antihipertensi, antihiperlipidemia, antiinfeksi, antiinflamasi, antianemia dan meningkatkan produksi ASI (Lestari et al., 2020).

Tanaman katuk (Sauropus androgynus (L.)Merr.) adalah salah satu tanaman yang memiliki senyawa metabolisme sekunder dengan berbagai potensi dan mengandung beberapa senyawa kimia, antara lain alkaloid papaverin, protein, lemak, vitamin, mineral, saponin, flavonoid dan tanin. Daun katuk dapat bekerja sebagai antioksidan yang disebabkan adanya senyawa golongan fenol yaitu flavonoid. Andarwulan et al.,(2010), menemukan bahwa daun katuk (mg/100 g daun segar) mengandung flavonoid total sebanyak $143 \mathrm{mg}$. Dari hasil skrining pendahuluan, ekstrak daun katuk mengandung senyawa flavonoida dengan nilai IC50 sebesar 80,81, dan termasuk dalam antioksidan yang sangat kuat (Zuhra et al.,2018).

Daun katuk sering digunakan dalam bentuk ekstrak sebagai antibakteri, tetapi dirasakan kurang efektif dan efisien. Maka perlu dikembangkan suatu sediaan farmasi untuk meningkatkan penggunaannya. Salah satu sediaan farmasi yang mudah kita gunakan adalah dalam bentuk sediaan salep, karena sediaan salep jika digunakan dengan konsisten sangat cocok untuk terapi penyakit seperti bakteri dan luka. Salep didefinisikan sebagai sediaan setengah padat yang mudah dioleskan dan digunakan sebagai obat luar. Keuntungan dari penggunan salep yaitu praktis, mudah dioleskan, dan dapat melindungi kulit seperti mencegah kontak permukaan kulit dengan larutan berair dan rangsang kulit (Anief, 2008).

Kandungan kimia dalam daun katuk berkhasiat untuk melindungi struktur sel, meningkatkan efektivitas vitamin C, anti inflamasi, mencegah keropos tulang, dan sebagai antibiotik alami. Fungsi lainnya yaitu berperan langsung sebagai antibiotik dengan mengganggu fungsi mikroorganisme seperti bakteri atau virus dan juga dapat meningkatkan imunitas tubuh (Middleton et al., 2000). 


\section{METODOLOGI PENELITIAN}

Penelitian ini menggunakan metode eksperimen, yakni pembuatan formulasi sedian salep dari ekstrak daun katuk. Telah dilaksanakan pada bulan juli 2021 sampai Agustus 2021 di Laboratorium Herbarium Jurusan Biologi FMIPA Pertanian USK, Laboratorium Analisis Pangan dan Hasil Pertanian USK dan Laboratorium Farmasetika Akademi Farmasi YPPM Mandiri Banda Aceh.

Alat-alat yang digunakan pada penelitian ini adalah gelas ukur, neraca analitis (timbangan analitik), corong, pengaduk, kertas $\mathrm{pH}$ (kertas lakmus), sudip, pot plastik, kertas perkamen, cawan petri, kaca objek, spatula, cawan porselen, beaker glass, lumpang dan alu. Bahan-bahan yang digunakan pada penelitian ini adalah ekstrak daun katuk (Sauropus androgynus (L.) Merr.) etanol 70\%, adeps lanae, dan vaselin album.

\subsection{Pembuatan Simplisia Daun Katuk}

Daun katuk dibersihkan dengan air mengalir, lalu daun katuk dipisahkan dari batangnya. Daun katuk ditimbang sebanyak 1 kg lalu dipotong-potong kecil. Daun katuk kemudian dikeringkan dengan suhu ruangan sampai daun katuknya benar-benar kering sehingga mudah disimplisiakan. Lalu daun katuk yang sudah kering disimplisiakan dengan cara diremas-remas sampai daun katuk hancur, kemudian ditimbang daun katuk sebagai berat kering. Simplisia yang sudah jadi di simpan dalam wadah yang terlindungi dari sinar matahari (Febria, 2012).

\subsection{Pembuatan Ekstrak Daun Katuk}

Pembuatan ekstrak etanol daun katuk dilakukan dengan cara maserasi yaitu sebanyak $200 \mathrm{~g}$ serbuk simplisia dimasukkan kedalam wadah, kemudian direndem dengan larutan etanol $70 \%$ sebanyak $1000 \mathrm{~mL}$ selanjutnya ditutup dengan penutup wadah selama 24 jam sambil sesekali diaduk. Sampel yang telah direndam tersebut disaring menggunakan kertas saring dan menghasilkan filtrat 1 dan residu 1. Residu yang ada selanjutnya ditambahkan dengan larutan etanol $70 \%$ sebanyak $1000 \mathrm{~mL}$, kemudian ditutup dengan wadah penutup dan didiamkan selama 24 jam sambil sesekali diaduk. Setelah penyimpanan 24 jam, dilakukan penyaringan dengan menggunakan kertas saring. Hasil dari penyaringan kedua ini menghasilkan filtrat 2 dan residu 2. Kemudian filtrat 1 dan 2 dicampurkan menjadi satu dan diuapkan menggunakan Rotary Vacuum Evaporator. Hasil yang diperoleh selanjutnya dipekatkan di atas Waterbath pada suhu $40^{\circ} \mathrm{C}$ hingga diperoleh ekstrak kental. Ekstrak disimpan dalam suhu dingin $5-10^{\circ} \mathrm{C}$ yang selanjutnya akan digunakan pada pembuatan salep (Djumaati et al., 2018).

\subsection{Formulasi Sediaan Salep Ekstrak Daun Katuk}

Formulasi standar basis salep menurut Novita et al., 2017:

Formulasi basis salep untuk $30 \mathrm{~g}$
R/ Adeps lanae
$4,5 \mathrm{~g}$
Vaselin Album
$25,5 \mathrm{~g}$
Mf. salep
$30 \mathrm{~g}$

Sediaan salep yang digunakan dalam penelitian ini memiliki konsentrasi ekstrak daun katuk yang berbeda-beda, yaitu 10\%, 15\% dan 20\% yang dibuat sebanyak 20 gram. Formulasi salep dari ekstrak daun katuk dapat dilihat pada tabel 1.

Tabel 1. Formulasi Salep Dari Ekstrak Daun Katuk

\begin{tabular}{llcccc}
\hline \multirow{2}{*}{ No } & \multicolumn{1}{c}{ Bahan } & \multicolumn{4}{c}{ Jumlah bahan $(\mathrm{g})$} \\
& & F0 & FI 10\% & FII 15\% & FII 20\% \\
\hline 1. & Ekstrak daun katuk & - & 2 & 3 & 4 \\
2. & Dasar salep & 20 & 18 & 17 & 16 \\
3. & M.f. salep & 20 & 20 & 20 & 20 \\
\hline
\end{tabular}

\subsection{Pembuatan Salep Ekstrak Daun Katuk}

\section{a. Pembuatan basis salep}

Pembuatan salep dari ekstrak daun katuk menggunakan basis salep adeps lanae dan vaselin album. Dalam pembuatan salep ekstrak daun katuk, pertama dilakukan penimbangan basis adeps lanae dan vaselin album sesuai dengan formulasi salep lalu dileburkan pada waterbath setelah semua bahan melebur kemudian digerus sampai homogen (Paju et al., 2013).

\section{b. Pencampuran basis salep dengan ekstrak daun katuk dengan cara:}

Menimbang ekstrak kental daun katuk dengan berat sesuai formulasi salep. Jumlah yang ingin dibuat yaitu $2 \mathrm{~g}$ ekstrak daun katuk untuk konsentrasi 10\%, $3 \mathrm{~g}$ ekstrak daun katuk untuk konsentrasi 15\% dan $4 \mathrm{~g}$ ekstrak daun katuk untuk konsentrasi 20\%. Kemudian ekstrak daun katuk yang telah ditimbang ditambahkan masing-masing basis salep dengan konsentrasi yang berbeda-beda yaitu 10\%. 15\% dan 20\%, kemudian digerus dalam mortir sampai homogen. Setelah homogen dimasukkan ke dalam pot salep kemudian beri lebel (Paju et al., 2013). 


\section{Journal of Pharmaceutical and Health Research}

\section{Vol 2, No 3, Oktober 2021, pp. 76-81 \\ ISSN 2721-0715 (media online) \\ DOI 10.47065/jharma.v2i3.1267}

\subsection{Evaluasi sediaan salep Ekstrak Daun Katuk}

\subsubsection{Uji Organoleptis}

Pemeriksaan organoleptis meliputi bentuk, warna, dan bau yang diamati secara visual (Suardi et al., 2008). Menurut Depkes RI, spesifikasi salep yang harus dipenuhi adalah memiliki bentuk sediaan padat, warna harus sesuai dengan spesifikasi pada saat pembuatan awal salep dan bau tidak tengik (Sari et al., 2016).

\subsubsection{Uji Homogenitas}

Pengujian homogenitas sediaan salep dilakukan dengan cara mengoleskan salep pada sekeping kaca objek atau bahan transparan lain yang harus menunjukkan susunan yang homogen. Salep yang homogen ditandai dengan tidak terdapat gumpalan pada hasil pengolesan, struktur yang rata dan memiliki warna yang seragam dari titik awal pengolesan sampai titik akhir pengolesan. Salep yang diuji diambil tiga tempat yaitu bagian atas, tengah dan bawah dari wadah salep (Sari et al., 2016).

\subsubsection{Uji Daya Sebar}

Sebanyak 0,5 gr salep diletakkan di atas kaca bulat lalu diletakkan satu kaca bulat lagi diatasnya dan dibiarkan selama 1 menit. Diameter sebar salep di ukur, setelah itu 100 gram beban ditambahkan lalu didiamkan selama 1 menit lalu di ukur diameter yang konstan (Pratimasari et al., 2015). Diameter daya sebar salep yang baik antara 5-7 cm (Sari et al., 2016).

\subsubsection{Uji pH}

1 gr salep diencerkan dengan $10 \mathrm{ml}$ akuades. Kertas lakmus $\mathrm{pH}$ dicelupkan ke dalam larutan yang diperiksa, dibiarkan beberapa saat. Lalu diamati warna yang dihasilkan oleh kertas lakmus. Warna tersebut kemudian dibandingkan dengan warna $\mathrm{pH}$ yang terdapat di kemasan. Nilai $\mathrm{pH}$ salep yang baik adalah 4,5-7 atau sesuai dengan nilai $\mathrm{pH}$ kulit manusia (swastika et al., 2013).

\subsubsection{Uji Stabilitas}

Pengujian kestabilan dilakukan dengan menyimpan sediaan salep ekstrak daun katuk selama 7 hari bertujuan untuk mengetahui ada atau tidaknya kestabilan dari sediaan salep ekstrak daun katuk yang disimpan pada suhu ruang di satu tempat yang sama (Febrihaq, 2019).

\subsubsection{Uji iritasi}

Lima sukarelawan uji wanita dipilih berdasarkan kriteria inklusi dan ekslusi. Uji iritasi terhadap kulit sukarelawan uji dilakukan dengan uji tempel terbuka. Uji tempel terbuka dilakukan dengan mengoleskan sedian pada lengan bawah, kemudian dibiarkan terbuka selama 24 jam dan diamati reaksi yang terjadi. Reaksi iritasi positif ditandai dengan adanya kemerahan, gatal-gatal, atau bengkak pada kulit lengan bawah yang diberi perlakuan (Tranggono dan Latifah, 2007).

\section{HASIL DAN PEMBAHASAN}

\subsection{Hasil Ekstraksi Daun Katuk (Sauropus androgynus (L.) Merr.)}

Serbuk daun katuk digunakan sebanyak 200 g. Kemudian serbuk dimaserasikan menggunakan pelarut etanol $70 \%$ sebanyak $2000 \mathrm{ml}$ yang dilakukan sebanyak dua kali pengulangan maserasi. Lalu disaring hingga terpisah dari ampasnya. Kemudian Ekstrak daun katuk diuapkan dan dipekatkan dengan rotary vaccum evaporator untuk mendapatkan hasil ekstrak kental. Hasil ekstrak kental sebanyak $63.8 \mathrm{~g}$ yang berwarna hijau pekat dan hasil rendeman yang didapatkan adalah $31,9 \%$.

\subsection{Hasil Uji Evaluasi Sediaan Salep Ekstrak Daun Katuk}

\subsubsection{Hasil Uji Organoleptis}

Uji organoleptis dilakukan selama 2 minggu penyimpanan dengan mengamati bentuk, bau, warna dari sediaan salep. Sedian salep yang baik adalah dengan bentuk setengah padat, warna seperti ekstrak dan bauk khas dari sampel daun katuk. Hasil uji organoleptis yang didapatkan dapat dilihat pada tabel 2.

Tabel 2. Hasil Uji Organoleptis

\begin{tabular}{ccccc}
\hline Minggu & Jenis salep & Bentuk & Bau & Warna \\
\hline \multirow{2}{*}{ I } & Formula 0 & Setengah padat & Tidak bau & Putih \\
& Formula I & Setengah padat & Berbau khas ekstrak & Hijau kehitaman \\
& Formula II & Setengah padat & Berbau khas ekstrak & Hijau kehitaman \\
& Formua III & Setengah padat & Berbau khas ekstrak & Hijau kehitaman \\
\hline
\end{tabular}




\section{Journal of Pharmaceutical and Health Research}

Vol 2, No 3, Oktober 2021, pp. 76-81

ISSN 2721-0715 (media online)

DOI 10.47065/jharma.v2i3.1267

\begin{tabular}{ccccc}
\hline Minggu & Jenis salep & Bentuk & Bau & Warna \\
\hline \multirow{3}{*}{ II } & Formula 0 & Setengah padat & Tidak bau & putih \\
& Formula I & Setengah padat & Berbau khas ekstrak & Hijau kehitaman \\
& Formula II & Setengah padat & Berbau khas ekstrak & Hijau kehitaman \\
& Formula III & Setengah padat & Berbau khas ekstrak & Hijau kehitaman \\
\hline
\end{tabular}

Berdasarkan evaluasi yang telah dilakukan hasil uji organoleptis sediaan salep ekstrak daun katuk dan basis salep yaitu memiliki bentuk setengah padat. Uji organoleptis dari sadiaan salep ekstrak daun katuk dan basis salep memiliki perbedaan dari segi warna, bentuk dan bau. Basis salep sebagai formulasi kontrol memiliki warna putih, bentuk setengah padat, dan tidak berbau. Sediaan salep ekstrak daun katuk sebagai formulasi I memiliki warna hijau kehitaman, bentuk setengah padat, dan bau khas ekstrak daun katuk. Sedian salep ekstrak daun katuk sebagai formulasi II memiliki warna hijau kehitaman, bentuk setengah padat, dan bau khas ekstrak daun katuk. Sediaan salep ekstrak daun katuk sebagai formulasi III memiliki warna hijau kehitaman, bentuk setengah padat, dan bau khas daun katuk.

\subsubsection{Uji Homogenitas}

Tabel 3. Hasil uji homogenitas

\begin{tabular}{cc}
\hline Jenis salep & Homogenitas \\
\hline Formula 0 & Homogen \\
Formula I & Homogen \\
Formula II & Homogen \\
Formula III & Homogen \\
\hline
\end{tabular}

Uji homogenitas bertujuan untuk mengetahui salep yang telah dibuat apakah tercampur merata antara zat aktif dengan basis salep. Hasil yang didapatkan dari uji homogenitas dari keempat konsentrasi menunjukan bahwa sediaan salep tercampur merata dan tidak terdapat butiran halus saat dioleskan pada kaca objek.

\subsubsection{Uji Daya Sebar}

Tabel 4. Hasil Uji Daya Sebar

\begin{tabular}{cc}
\hline Jenis salep & daya sebar $(\mathrm{cm})$ \\
\hline Formula 0 & $5 \mathrm{~cm}$ \\
Formula I & $5,2 \mathrm{~cm}$ \\
Formula II & $5,8 \mathrm{~cm}$ \\
Formula III & $6 \mathrm{~cm}$ \\
\hline
\end{tabular}

Hasil uji daya sebar berhubungan dengan penyebaran salep pada kulit yang telah dilakukan pada formula kontrol, formula 1. Formula 2 dan formula 3 mendapatkan hasil bahwa sediaan salep sangat mudah menyebar dengan daya sebar yang baik. Sediaan salep formula kontrol, formula 1, formula 2 dan formula 3 memenuhi parameter daya sebar dimana diameter daya sebar yang baik adalah $5-7 \mathrm{~cm}$.

\subsubsection{Uji pH}

Tabel 5. Hasil Uji pH

\begin{tabular}{ccc}
\hline Minggu & Jenis salep & $\mathrm{pH}$ \\
\hline \multirow{3}{*}{ I } & Formula 0 & 7 \\
& Formula I & 7 \\
& Formula II & 6 \\
& Formula III & 6 \\
\cline { 2 - 3 } II & Formula 0 & 7 \\
& Formula I & 7 \\
& Formula II & 7 \\
\hline
\end{tabular}

Uji pH dilakukan menggunakan kertas lakmus pada keempat formulasi sediaan ekstrak daun katuk dan didapatkan nilai $\mathrm{pH}$ yang berada di rentang 6-7 yang menunjukkan bahwa sediaan salep tersebut telah memenuhi persyaratan $\mathrm{pH}$ yang sesuai pada kulit yaitu antara 4,5-7 (swastika et al., 2013). 


\section{Journal of Pharmaceutical and Health Research}

\section{Vol 2, No 3, Oktober 2021, pp. 76-81 \\ ISSN 2721-0715 (media online) \\ DOI 10.47065/jharma.v2i3.1267}

\subsubsection{Uji Stabilitas}

Tabel 6. Hasil uji Stabilitas Sediaan Salep Ekstrak Daun Katuk

\begin{tabular}{cc}
\hline Jenis salep & Stabilitas \\
\hline Formula 0 & Stabil \\
Formula I & Stabil \\
Formula II & Stabil \\
Formula III & Stabil \\
\hline
\end{tabular}

Hasil uji stabilitas pada formulasi kontrol, formulasi 1, formulasi 2 dan formulasi 3 yang disimpan selama 2 minggu pada suhu ruang ditempat yang sama mendapatkan hasil stabil dan tidak berubah bentuk, warna dan bau.

\subsubsection{Uji Iritasi}

Tabel 7. Hasil Uji Iritasi

\begin{tabular}{cccccc}
\hline \multirow{2}{*}{ Jenis salep } & 1 & 2 & 3 & 4 & 5 \\
\hline Formula 0 & - & - & - & - & - \\
Formula I & - & - & - & - & - \\
Formula II & - & - & - & - & - \\
Formula III & - & - & - & - & - \\
\hline
\end{tabular}

Uji iritasi dilakukan pada 5 sukarelawan uji, dengan cara mengoleskan salep ekstrak daun katuk pada kulit tangan dan diamati selama 24 jam. Dari 5 sukarelawan uji tidak mengalami gejala iritasi yang berupa kemerahan, gatal-gatal, bengkak, terlalu panas dan perih pada permukaan kulit setelah dioleskan sediaan salep yang mengandung ekstrak daun katuk yang diamati selama 24 jam. Hal ini dikarenakan $\mathrm{pH}$ sediaan salep yang dihasilkan adalah 6-7, sesuai dengan $\mathrm{pH}$ yang dapat ditolerir oleh kulit.

\section{KESIMPULAN}

Sediaan salep ekstrak daun katuk berbentuk setengah padat dan berwarna khas ekstrak daun katuk serta memiliki bau ekstrak sendiri. Sedian salep dari ekstrak daun katuk memenuhi persyaratan evaluasi dengan karakteristik yang meliputi organoleptis, homogenitas, $\mathrm{pH}$, daya sebar, uji stabilitas dan uji stabilitas. Kestabilitas sediaan salep ekstrak daun katuk dalam penyimpanan 2 minggu yaitu stabil, tidak terjadi perubahan warna, bau dan bentuk dan tidak menimbulkan iritasi pada kulit saat pengolesan salep.

\section{REFERENCES}

Andarwulan, N., Batari, R., Sandrasari, D. A., Bolling, B., \& Wijaya, H. (2010). Flavonoid content and antioxidant activity of vegetables from Indonesia. Food chemistry, 121(4), 1231-1235.

Anief, M. (2008). Ilmu Meracik Obat. Jakarta: Cetakan Keempatbelas.

Djumaati, F. (2018). Formulasi Sediaan Salep Ekstrak Etanol Daunkelor (Moringa oleifera Lamk.) Dan Uji Aktivitas Antibakterinya Terhadap Bakteri Staphylococcus aureus. Pharmacon, 7(1).

Febria, S. (2012). Ekstrak Daun Katuk (Sauropus Androgynus (L.)Merr.) Sebagai Obat Luka Insisi Kronis Dalam Sediaan Salep Dan Krim.

Febrihaq, D. (2019). Formulasi dan Evaluasi Sediaan Lotion dari Minyak Lemon (Citrus limon L.) dengan Variasi Konsentrasi Span 80 dan Tween 80 sebagai Emulgator. KTI. Palembang: Politeknik Kesehatan Palembang Jurusan Farmasi.

Lestari, F. A., Hajrin, W., \& Hanifa, N. I. (2020). Optimasi Formula Krim Ekstrak Daun Katuk (Sauropus Androgynus (L.)Merr.) Variasi Konsentrasi Asam Stearat, Trietanolamin, dan Gliserin. Jurnal Kefarmasian Indonesia, 10(2).

Middleton, E Jr, Kandaswami C. And Theoharides, T. C. 2000 The Effects of Plant Flavonoids on Mammalian Cells: Implication For Inflammantion, Heart Disease, And Cancer. Pharmacelogical Review, 2.

Novita, R., Munira, M., \& Hayati, R. (2017). Formulasi Sediaan Salep Ekstrak Etanol Pliek U Sebagai Antibakteri. AcTion: Aceh Nutrition Journal, 2(2), 103-108.

Paju, N., Yamlean, P. V., \& Kojong, N. (2013). Uji efektivitas salep ekstrak daun binahong (Anredera cordifolia (Ten.) Steenis) pada kelinci (Oryctolagus cuniculus) yang terinfeksi bakteri Staphylococcus aureus. Pharmacon, 2(1).

Pratimasari, D., Sugihartini, N., \& Yuwono, T. (2015). Evaluasi sifat fisik dan uji iritasi sediaan salep minyak atsiri bunga cengkeh dalam basis larut air. Jurnal Ilmiah Farmasi, 11(1), 9-15.

Sari, R., Nurbaeti, S. N., \& Pratiwi, L. (2016). Optimasi kombinasi karbopol 940 dan HPMC terhadap sifat fisik gel ekstrak dan fraksi metanol daun kesum (Polygonum minus Huds.) dengan metode Simplex Lattice Design. Pharmaceutical Sciences \& Research, 3(2).

Suardi, M., Armenia, dan Maryawati, A. (2008). Formulasi dan Uji Klinik Gel Anti Jerawat Benzoil Peroksida-HPMC. Tanggal akses: 7 November 2011.

Swastika, A, Mufrod \& Purwanto,. 2013. Aktivitas Antioksidan Krim Ekstrak Sari Tomat (Solanum lycopersicum L.). Trad Med Journal. 


\section{Journal of Pharmaceutical and Health Research}

Vol 2, No 3, Oktober 2021, pp. 76-81

ISSN 2721-0715 (media online)

DOI 10.47065/jharma.v2i3.1267

18(3): 132-140.

Tranggono, R. I., \& Latifah, F. (2007). Buku pegangan ilmu pengetahuan kosmetik. Jakarta: PT. Gramedia Pustaka Utama.

Zuhra, C. F., Tarigan, J. B., \& Sihotang, H. (2008). Aktivitas antioksidan senyawa flavonoid dari daun katuk (Sauropus androgynus (L.) Merr.). Jurnal Biologi Sumatera, 3(1), 7-10. 